\title{
Developing instruments for measuring the level of early childhood development
}

\author{
${ }^{* 1}$ I Wayan Gunartha; ${ }^{2}$ Tajularipin Sulaiman; ${ }^{3}$ Siti Partini Suardiman; ${ }^{4}$ Badrun \\ Kartowagiran \\ ${ }^{1}$ Faculty of Language and Arts Education, Institut Keguruan dan Ilmu Pendidikan PGRI Bali \\ Jl. Seroja, Tonja, Denpasar Timur, Kota Denpasar, Bali 80235, Indonesia \\ ${ }^{2}$ Faculty of Educational Studies, Universiti Putra Malaysia \\ Persiaran Masjid, 43400 Serdang, Selangor, Malaysia \\ ${ }^{3}$ Faculty of Teacher Training and Educational Sciences, Universitas Ahmad Dahlan \\ Jl. Ahmad Yani (Ringroad Selatan), Tamanan, Banguntapan, Bantul, Yogyakarta 55166, Indonesia \\ ${ }^{4}$ Faculty of Engineering, Universitas Negeri Yogyakarta \\ Jl. Colombo No. 1, Karangmalang, Depok, Sleman, Yogyakarta 55281, Indonesia \\ ${ }^{*}$ Corresponding Author. E-mail: w.gunartha@yahoo.com
}

Submitted: 11 January 2020 | Revised: 17 April 2020 | Accepted: 20 April 2020

\begin{abstract}
The aims of the study were to: (1) develop a set of instruments to measure the level of early childhood development (kindergarten group B), and (2) assess the quality of the developed instruments. This study is developmental research. The samples of the study were the students of kindergarten group B. The developed instrument was a set of questionnaires. Instrument testing was carried out in three stages with the number of subjects increased on each stage. The validity analysis of the questionnaire used confirmatory factor analysis (CFA). The reliability estimation of the questionnaire used composite reliability. The results of the study are in the form of instruments for measuring the level of early childhood development, which consists of an instrument to measure religious morality, social-emotional, language, cognitive, and physical-motor development. Based on field study, all instruments have a good fit model, construct validity, and reliability that meet the academic requirements of early childhood education.
\end{abstract}

Keywords: instrument development, early childhood, kindergarten, potential

How to cite: Gunartha, I., Sulaiman, T., Suardiman, S., \& Kartowagiran, B. (2020). Developing instruments for measuring the level of early childhood development. REiD (Research and Evaluation in Education), 6(1), 1-9. doi:https://doi.org/10.21831/reid.v6i1.21996

\section{Introduction}

Early childhood is the most important and fundamental beginning period. Therefore, early childhood is often called the Golden Ages. This period is also often called a sensitive period, the period of play, the critical period because this period will affect the future lives of the child. According to Woolfolk (2007, p. 23), approximately one month after conception, human brain development has begun. Neuron cells appear with incredible speed, i.e. 50,000 to 1,000,000 per second for approximately three months. When born, we have had about 100 to 200 billion neurons, and each neuron has about 2,500 synapses. Synapses that are unused or not getting stimulation from the environment will be trimmed (synaptic pruning). Berk (2007, p. 121) added that the complexity of connections between neurons will determine the child's level of intelligence. The same thing was said by Miller and Cumming (Rushton, 2011, p. 92). 
All of the aforementioned statements show that the growth and development of the brain (synapses) are determined by the stimuli or stimulus provided to the child and the activities undertaken by children. Thus, children who are growing and developing must be activated by providing a variety of stimuli and appropriate activities. This is the important role of early childhood education (ECE) as a form of physical and psychosocial stimulation whether at home or in early childhood institutions, besides nutrition and health care. Hence, according to Valentine, Thomson, and Antcliff (2009, p. 196), in Australia, even early education and parenting has got priority policy.

An appropriate stimulation, as well as nutrition, parenting, and also health services at an early age, will develop all of children's potential, including their physical, cognitive, language, art, social-emotional, self-discipline, religious values, self-concept, and also self-reliance, will develop optimally. Therefore, early childhood education is expected to contribute significantly to the improvement of human resources (HR) quality, which will make our nation to be high quality and full of competitiveness in the future.

The importance of stimulation obtained by children in early childhood education institutions is also proved empirically by many experts. Samuelsson (2011, p. 109) in her research on the role of early childhood education said that learning at an early age has an influence in the future, for example, the success of the school, as well as the attitude and attention, will be formed early on. Mann and Reynolds (2006, p. 153) concluded that preschool intervention correlates with a reduction in the incidence, frequency, and severity of the delinquency at age 18 years.

Ashiabi (2007, pp. 205-206) states that a lot of advantages can be attained to let children playing with other children. For example, sociodramatic playing can improve a child's ability to imagine before acting, taking a role, empathy, altruism, and also emotions and rules understanding. Moreover, negotiation and problem-solving skills also increase, such as the ability to work cooperatively with others, share, self-control, and working with the group. In other words, sociodramatic play can enhance children's social and emotional development optimally. A similar study was conducted by Beard and Sugai (2004, p. 408).

By the importance of early childhood education, the government's attention to developing early childhood education becomes greater. Since 2000, Early Childhood Education (ECE) started to become a central issue in education, including in Indonesia, even more, Erman Syamsudin, Director of Early Childhood Development (Ministry of National Education of Republic of Indonesia, 2011, p. vii), stated that early childhood education is one of the priority programs of national education development. Early Childhood Education (ECE) services are expected to nurture, grow, and develop the whole early childhood potential optimally so it can form the basic ability and behavior according to the children's development stage.

In response to the government policy, the public has shown their concern for the problems of education, protection, and care of early-aged children with a variety of services in accordance with their conditions and capabilities. Public awareness of the importance of early childhood education in the optimal development of children's potential has been shown with various active participation in the implementation and improvement of services. Although various policies have been issued by the government, in fact, there are still many problems that exist in the implementation of early childhood services including in Badung Regency, Province of Bali. There are still many children who have not gained early childhood services. This fact acknowledged by the General Director of Early Childhood Education, Non-Formal and Informal that although the policies have been established and socialized related to early childhood development, in fact, of the 28, eight million children aged 0-6 years in late 2009, who gained an early childhood education services is just around $53.7 \%$ (Ministry of National Education of Republic of Indonesia, 2011, p. iii).

Research by Hiryanto (2007) about the mapping of the quality achievement level of early childhood programs in Yogyakarta re- 
veals that by the views of the implementation guidelines to the suitability of early childhood education with the real conditions of the program implementation based on the ten benchmarks of national education, in the implementation of early childhood education in the Yogyakarta Province, some problems can be found as follows: (1) The variation in the implementation of education; (2) The existence of the age groupings that do not fit the guidelines because of limited infrastructure and educators; (3) There are still some educators who have not received training; (4) The ratio of the teachers and students number is not ideal.

The research by Hermawati (2007) in a children daycare in Beringharjo, Yogyakarta, found two drawbacks of the input variables, namely, the teacher's educational background and caregiver qualifications that are not relevant to the tasks. In the process variables, the problem is the immeasurability of mentoring by a caregiver. It is associated with the majority of low caregiver's education. In addition, the assistance has not been done regularly by the organizers. The public access to the children's daycare Beringharjo is limited because of limited capacity. Based on the preliminary study conducted at the early childhood institution in Badung Regency, Province of Bali, it was also found many problems related to the implementation of early childhood education (ECE), such as the quality and quantity of early childhood teachers are still relatively low and the number of teachers is on the average of three to four people. In terms of process, the kindergarten student has been taught reading, writing, and arithmetic skills because, according to the teacher, if it is not done, then no parents want to enroll their children to the institution.

In order to give good quality of early childhood education (ECE), in accordance with the existing standards, early childhood education services need to be evaluated regularly. According to Nugraha (2010, p. 3), good quality of early childhood education service is regularly evaluated and the results are acted upon appropriately. The same opinions are also expressed by Mardapi (2012, p. 12), that the improvement of the education quality can be achieved through improving the quality of learning by the improvement of the quality of the assessment system. Therefore, the availability of quality evaluation instruments is very important, in which it can be used by the government to evaluate early childhood education services continuously. By the results of evaluation activities, we will be able to know the things that have been achieved, whether a program can meet the established criteria or not.

Currently, the evaluation of early childhood services internally has not done thoroughly. Likewise, in Bali Province, even in Badung Regency, based on the preliminary study which has been conducted, the Department of Education has never done an evaluation of the existed early childhood services. The quality determination of early childhood institutions is often based on the frequency of competition participation and the number of early childhood learners. This is caused by the absence of evaluation instruments of early childhood services that have been tried and tested, both in terms of validity and reliability. The evaluation results will provide accurate information when obtained through evaluation using reliable instruments. Until now, the government, especially the Badung Department of Education, has not had a standard instrument for evaluation that can be used by the Department of Education or by the head of the kindergarten institution as an internal evaluation.

The education service is a system which consists of interlinked components and they mutually determine each other. These components are the input, process, and product. The component of inputs includes infrastructure, students, teachers, curriculum, and also subject matter. The component of processes includes lesson planning, implementation, and evaluation. The component of products on early childhood education services includes the achievement level of early childhood development, such as moral religious, socialemotional, language, cognitive, and physicalmotor development. In evaluating early childhood education services, these components should be evaluated continuously. Therefore, it is necessary to develop an instrument to 
evaluate the inputs, processes, and products of early childhood services. Based on that description, the instruments developed in this study is only an instrument for measuring the products, that is, an instrument to evaluate the achievement level of the early childhood development, which includes: (a) moral-religious, (b) social-emotional, (c) language, (d) cognitive, and (e) physical-motor. This is caused by the limited costs, energy, and time available.

Based on those aforementioned backgrounds, the problems in this study are as follows. How is the instrument for measuring the level of childhood development? How is the quality of the developed instruments, both in terms of validity and reliability? Based on the problems, the purpose of this research is to develop evaluation instruments that can be used to evaluate the level of early childhood development, particularly for kindergarten group B so as to provide complete and accurate information for program managers and to assess the quality of the evaluation instruments developed.

The products of this study are a set of an evaluation instrument for early childhood education services, particularly for kindergarten group B. The evaluation instrument of early childhood education services limited to instruments tends to measure the achievement level of early childhood development, which includes moral-religious, social-emotional, language, cognitive, and physical-motor development. The development of an evaluation model for early childhood services program is very beneficial, both theoretically and practically. Theoretically, this study is useful as a contribution to developing the existed evaluation methodology to generate new concepts in the field of evaluation science. Practically, the results of this study are useful for teachers, principals of early childhood/ kindergarten, as well as the Department of Education. For teachers in early childhood education (ECE), a kindergarten teacher, in particular, this instrument can be used to measure the effectiveness of the performed services and the results can be useful as a basis to make corrections to educational services.

\section{Method}

\section{Development Model}

This study is a research and development $(\mathrm{R} \& \mathrm{D})$, which aims to produce a product in the form of a set of instruments in order to evaluate the level of early-aged children's development (specifically kindergarten group B). The development research adopts the model which was proposed by Borg and Gall (1983, p. 775). The ten steps of development by Borg and Gall were then simplified into four steps, namely: (1) preliminary investigation, (2) design phase, (3) testing, evaluation, and revision, and also (4) implementation.

In the early stages, we conducted several activities, including a preliminary study, review the theory of instrument evaluation models, early childhood education, as well as review the results of research that has been done. In the design phase, the draft instrument was designed in order to measure the level of early childhood development, which consists of instruments for measuring products of services and the test design. In the pilot, evaluation, and revision phase, expert validation and testing of the instruments that have been designed in kindergarten were conducted. The data of test results were then analyzed. If the results of the analysis show that the instrument is not yet good, then it can be revised and tested again until a final prototype eligible fit model (good prototype). Tests were conducted in three phases. In the implementation phase, the instruments that have been well and subsequently tested were implemented.

\section{Development Procedure}

Several steps were taken in developing the instrument for measuring the level of early childhood development. Each step is elaborated as follows.

\section{Drafting of the Design}

At this stage, evaluation instruments to evaluate the product of early childhood services were structured, which consist of instruments for measuring religious morality, socialemotional, language, cognitive, and physical- 
motor development. All of those instruments were in the form of a questionnaire on a Likert scale with five points. These instruments are the first draft.

\section{Expert Judgment}

In order to check the content validity and refine the instrument draft, it was validated by experts, namely, academicians or lecturers and practitioners (kindergarten teacher), and also the user of the instrument (head/ deputy head of the kindergarten). The expert validation process used FGD (focus group discussions) model. The implementation of the FGD was conducted in two stages. The first FGD was conducted by ten academicians (lecturers) from the post-graduate program of Universitas Negeri Yogyakarta. When the instrument was revised in accordance with academicians' suggestions (lecturers), it was followed by another FGD and readability test by three kindergarten heads and also 17 kindergarten teachers. After the test was carried out, it was continued by the assessment of the instrument.

Tests

The draft of the instrument that has been revised based on the advice obtained in the FGD was piloted in kindergarten to determine the fit model of the measurement, construct validity, and reliability. The instrument test was conducted in three stages, namely, the first, second, and third with the increasing number of test subjects. The numbers of kindergarten were: 10, 13, and 18 and 160, 260, and 360 kindergarten children as the subject.

\section{Data Analysis}

The data about the comprehensiveness and also clarity of the instrument which were obtained from the experts were then analyzed descriptively. The data which were taken from the results of the field test were then analyzed using Confirmatory Factor Analysis (CFA) in order to find out the goodness of fit $(\mathrm{GoF})$ as well as determine the validity and reliability, with the 8.8 Lisrel program. In determining the goodness of fit, several indicators were employed, including: (a) the value of chisquare $\mathrm{p}$-value $\geq 0.05$, (b) root mean square error of approximation (RMSEA) $\leq 0.08$, and goodness of fit index (GFI) $\geq 0.9$ (Ghozali \& Fuad, 2008, pp. 29-31; Latan, 2012, p. 53). The construct reliability was calculated based on lambda $(\lambda)$ for each indicator, and the error variance $(\delta)$ indicator.

In the descriptive-qualitative analysis, the average score of the quantitative data that were obtained through an assessment instrument was calculated, then were converted into qualitative data with scale 5 , and then finally were interpreted qualitatively. The results of the qualitative analysis were used as the basis for determining whether the developed instrument was good or not. In converting the quantitative data into qualitative data with scale 5 , a modification of rules which were developed by Sudijono (2011, p. 329) was employed. The criteria of the instrument assessment which were used are presented in Table 1.

\section{Implementation}

After the last product of the instrument had been analyzed, a good prototype was implemented in 18 kindergartens. When it is depicted in the chart, the whole developing process of the instrument model of the early childhood development is clearly illustrated in Figure 1.

Table 1. Criteria of Instrument Assessment

\begin{tabular}{ccl}
\hline Average Score & Qualification & Conclusion \\
\hline$>4.2$ & Very good & Can be an example \\
$>3.4-4.2$ & Good & Can be used without any revision \\
$>2.6-3.4$ & Quite good & Can be used with a little revision \\
$>1.8-2.6$ & Less good & Can be used with some revision \\
$\leq 1.8$ & Bad & Cannot be an example \\
\hline
\end{tabular}




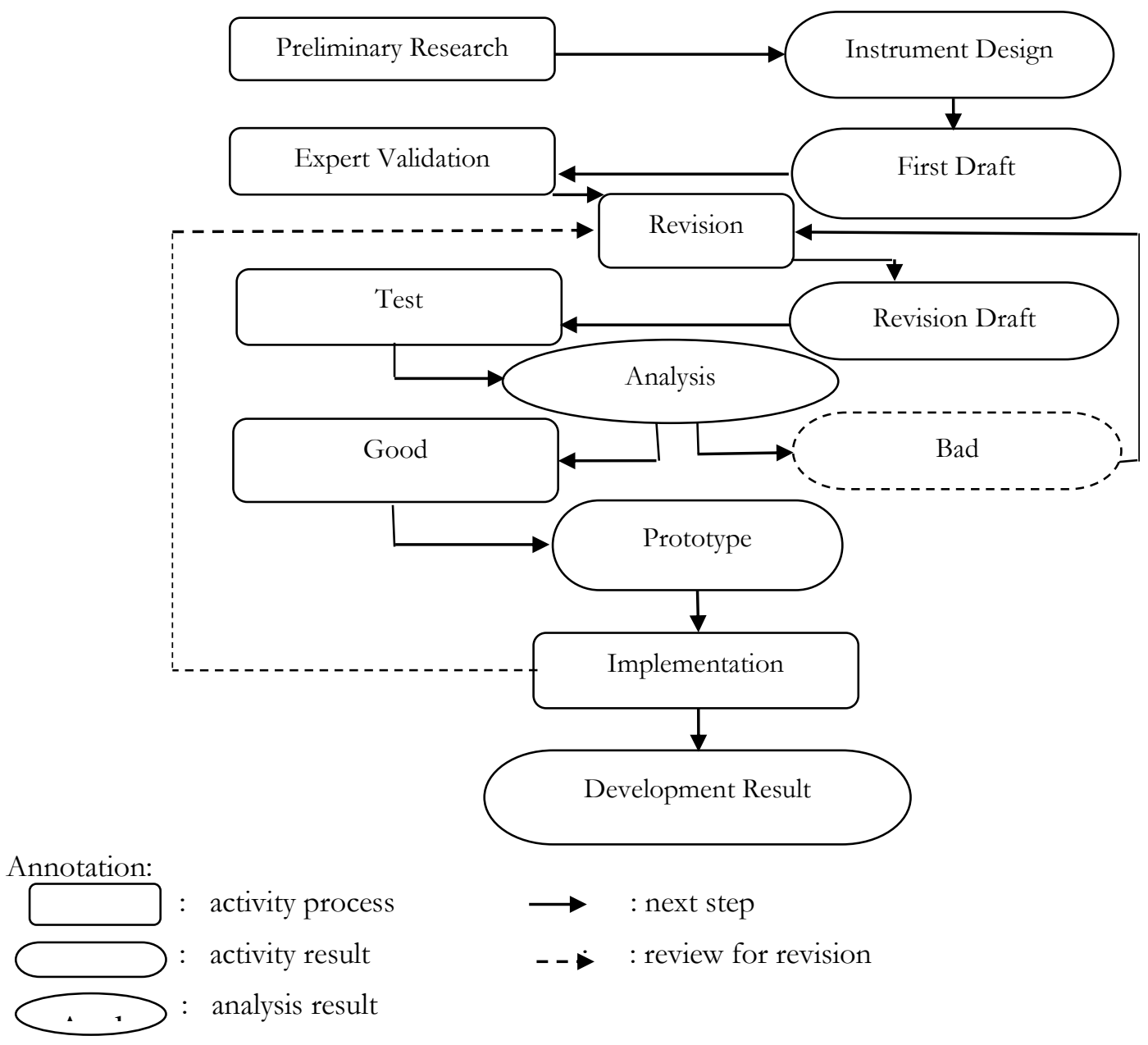

Figure 1. Flowchart of Instrument Model Development Procedure

Table 2. Instrument of Development Result

\begin{tabular}{lll}
\hline \multicolumn{2}{c}{ Instrument for Evaluating Early Childhood Services } & \\
\hline \multicolumn{1}{c}{ Instrument } & \multicolumn{1}{c}{ Evaluated Item } & Instrument Form \\
\hline Instrument for measuring the level & Achievement Level of Development: & \\
of early childhood development & a. Moral-Religious & Questionnaire \\
& b. Social-Emotional & Questionnaire \\
& c. Cognitive & Questionnaire \\
& d. Language & Questionnaire \\
& e. Physical-Motor & Questionnaire \\
\hline
\end{tabular}

\section{Findings and Discussion}

The instrument for measuring the level of early childhood development consists of five components, namely the instruments for measuring the development of moral-religious, social-emotional, language, cognitive, as well as physical-motor components. The type of the product instrument of the early childhood services developed is clearly presented in Table 2.

\section{Validation Result of Experts and Practitioners}

The instrument assessment by experts and practitioners was directed into four main aspects, namely: (a) the clarity of instrument guidance, (b) the completeness of instrument indicators, (c) the suitability of the indicators with the point, and (d) the effectiveness of Indonesian. The assessment used a scale of 5 with the lowest score was 1 and 5 was the highest. 
Based on the average score given by the experts, the mean obtained is 4.1 in total. In line with the conversion guidelines, the mean is at intervals of 3.4 to 4.2 and is classified as good. Based on the assessment conducted by teachers and heads of kindergarten, it is obtained a mean score of 4.29 in total. The mean score according to those criteria is also quite good. The total mean score of the two assessors groups is 4.2 It means that the instrument has been well conducted and can be used without any revision, shown in Table 3.

\section{Instruments Measurement Model}

Based on the analysis, all items on all instruments of the three pilot phases are significant ( $t>1.96)$, meaning that all items can be used to measure the construct well. In the third test, there are some items of achievement level instruments for language development that have smaller factor loading than 0.5 , i.e. 0.49 and 0.48 . Since it is approaching 0.5 , then it is rounded to 0.5 . Thus, all instruments have good construct validity. By look- ing at the model fit, on the third test, all requirements of model fit are met, both the pvalue $(\geq 0.05)$, RMSEA $(\leq 0.08)$, and GFI $(\geq$ $0.9)$. The construct reliability (CR) of all instruments are above 0.7 in all three stages of the test. Thus, based on the three stages of the test, all of the instruments have good construct validity, reliability, and goodness of fit. Those three phases' analyses are presented in Table 4.

In this study, five instruments for measuring the level of early childhood development were developed, namely: instruments for measuring moral-religious, social, language, cognitive, and physical-motor development. The instrument developed is in the form of a questionnaire. Instrument indicators are based on indicators of the level of achievement of early childhood development contained in the Regulation of the Minister of National Education No. 58 of 2009 on the Standard for Early Childhood Education, specifically the standard level of achievement of

Table 3. Recapitulation of Experts and Practitioners Validation

\begin{tabular}{lccc}
\hline \multicolumn{1}{c}{ Validator } & Validator Number & Average of Score & Qualification \\
\hline Experts & 10 & 4.10 & Good \\
Practitioners & 20 & 4.29 & Good \\
Total & 30 & 8.40 & - \\
& & 4.2 & Good \\
\hline
\end{tabular}

Table 4. Summary of Analysis Result for Instrument Measurement Model of Product and Outcome

\begin{tabular}{|c|c|c|c|c|c|c|c|c|}
\hline \multirow{2}{*}{ Instrument } & \multirow{2}{*}{$\begin{array}{l}\text { Number } \\
\text { of Point }\end{array}$} & \multirow{2}{*}{$\begin{array}{l}\text { Test } \\
\text { No. }\end{array}$} & \multicolumn{2}{|c|}{ Chi-Square } & \multirow{2}{*}{ RMSEA } & \multirow{2}{*}{ GFI } & \multirow{2}{*}{$\lambda<0.5$} & \multirow{2}{*}{ CR } \\
\hline & & & Score & p-value & & & & \\
\hline Moral-Religious & 25 & 1 & 308.30 & 0.07 & 0.029 & 0.87 & 2 & 0.89 \\
\hline \multirow[t]{2}{*}{ Development } & & 2 & 311.77 & 0.058 & 0.023 & 0.91 & - & 0.91 \\
\hline & & 3 & 307.31 & 0.075 & 0.019 & 0.94 & - & 0.91 \\
\hline Social-Emotional & 26 & 1 & 330.54 & 0.081 & 0.027 & 0.86 & - & 0.92 \\
\hline \multirow{2}{*}{ Development } & & 2 & 333.69 & 0.07 & 0.022 & 0.91 & - & 0.91 \\
\hline & & 3 & 331.38 & 0.089 & 0.018 & 0.93 & - & 0.92 \\
\hline Language & 24 & 1 & 282.39 & 0.060 & 0.030 & 0.87 & - & 0.70 \\
\hline \multirow[t]{2}{*}{ Development } & & 2 & 276.32 & 0.089 & 0.022 & 0.90 & - & 0.75 \\
\hline & & 3 & 286.48 & 0.051 & 0.02 & 0.94 & 2 & 0.82 \\
\hline Cognitive & 26 & 1 & 331.27 & 0.066 & 0.028 & 0.86 & - & 0.87 \\
\hline \multirow[t]{2}{*}{ Deevelopment } & & 2 & 326.05 & 0.089 & 0.021 & 0.91 & 2 & 0.80 \\
\hline & & 3 & 330.72 & 0.075 & 0.018 & 0.93 & 1 & 0.76 \\
\hline Physical-Motor & 27 & 1 & 356.76 & 0.077 & 0.027 & 0.86 & 4 & 0.72 \\
\hline \multirow[t]{2}{*}{ Development } & & 2 & 351.72 & 0.094 & 0.02 & 0.91 & 3 & 0.85 \\
\hline & & 3 & 355.86 & 0.076 & 0.018 & 0.93 & - & 0.82 \\
\hline \multirow[t]{3}{*}{ Life Skills } & 30 & 1 & 439.09 & 0.081 & 0.025 & 0.84 & 1 & 0.72 \\
\hline & & 2 & 437.05 & 0.092 & 0.019 & 0.90 & - & 0.76 \\
\hline & & 3 & 447.32 & 0.055 & 0.018 & 0.92 & 2 & 0.74 \\
\hline
\end{tabular}


development. The procedure for developing this instrument follows five steps, namely: (1) the design preparation phase, (2) the expert validation phase, (3) the testing phase, (4) the data analysis phase, and (5) the implementation phase. The draft instruments that have been compiled are then validated by experts to see indicator depth, formulation of questions or statements, language effectiveness, and others. The experts who validated the instrument consisted of ten peoples, who came from several fields of science, namely: two measurement experts, three evaluation experts, one education management expert, two primary education experts, and two childhood education experts. The goal is that the instrument can be assessed in various aspects, so as to produce a quality instrument.

After being revised based on the FGD input, the instrument was tested to determine the construct validity and reliability. The trial was conducted in three stages, with the number of trial subjects increased. Two assumptions underlie the thinking of why the test was conducted in three stages, namely: (1) increasing variety and the number of trial subjects three times expected to reach all kinds of characteristics, both kindergarten and existing students, and (2) with the representation of all kindergarten characteristics and students, then a good instrument will be obtained, which is an instrument that can be applied to all existing kindergarten.

Based on the results of the test data analysis that conducted from the first stage to the third stage, the following results were obtained. The results of the first phase of the trial show that the five instruments developed were still lacking. After the items points were revised, the second trial was conducted. The results of the second phase of the trial (main trial) show that the fit model of instrument had become better. Only some items of instruments still have deficiency. The items of instrument was revised again and the third trial was conducted. In this study, all the poor instruments have been revised in two stages, the results of the third stage of the test show that all instruments have good fit model, validity, and reliability. Therefore, all instruments developed have a good measurement model, because: (a) all values of $\chi 2$ are low ( $p \geq 0.05)$, (b) all RMSEA $\leq 0.08$, and (c) all GFI values $\geq 0.9$. The coefficients of construct reliability (CR) are all above 0.7. Thus, all instruments developed have good quality.

\section{Conclusion}

Based on the research findings, two points of conclusion can be drawn. Each point is elaborated as follows. (1) The instruments for measuring the achievement level of early childhood development developed in this research consist of five components: instrument to evaluate the achievement level of moral-religious, social-emotional, cognitive, language, and physical-motor development. (2) According to the assessment of experts and practitioners, the instruments developed have good quality and can be used without any revision. All developed instruments have good validity, reliability, and goodness of fit.

\section{References}

Ashiabi, G. S. (2007). Play in the preschool classroom: Its socioemotional significance and the teacher's role in play. Early Childhood Education Journal, 35(2), 199-207. https://doi.org/ 10.1007/s10643-007-0165-8

Beard, K. Y., \& Sugai, G. (2004). First step to success: An early intervention for elementary children at risk for antisocial behavior. Behavioral Disorders, 29(4), 396-409. https://doi.org/10.1177/ 019874290402900407

Berk, L. E. (2007). Development through the lifespan (4th ed.). Boston, MA: Pearson Education.

Borg, W. R., \& Gall, M. D. (1983). Educational research: An introduction (4th ed.). New York, NY: Longman.

Ghozali, I., \& Fuad, F. (2008). Structural Equation Modeling: Teori, konsep, dan aplikasi dengan program Lisrel 8.80 . Semarang: Badan Penerbit Universitas Diponogoro.

Hermawati, I. (2007). Evaluasi program Pendidikan Anak Usia Dini (PAUD) bagi 


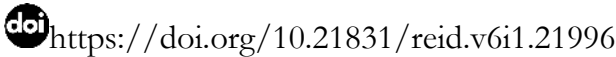
I Wayan Gunartha, Tajularipin Sulaiman, Siti Partini Suardiman, \& Badrun Kartowagiran

anak dari keluarga miskin di tempat penitipan anak (TPA) Beringharjo, Yogyakarta. Yogyakarta: Departemen Sosial RI, Badan Pendidikan dan Penelitian Kesejahteraan Sosial, Balai Besar Penelitian dan Pengembangan, Pelayanan Kesejahteraan Sosial.

Hiryanto, H. (2007). Pemetaan tingkat pencapaian mutu program pendidikan anak usia dini (PAUD) di Provinsi DIY. (Laporan penelitian, tidak diterbitkan). Yogyakarta: Lembaga penelitian UNY. Diklus: Jurnal Pendidikan Luar Sekolah, 6(11), 127-149. Retrieved from https://journal.uny.ac.id/index.php/dik lus/article/view/5787

Latan, H. (2012). Structural Equation Modeling: Konsep dan aplikasi menggunakan program Lisrel 8.80. Bandung: Alfabeta.

Mann, E. A., \& Reynolds, A. J. (2006). Early intervention and juvenile delinquency prevention: Evidence from the Chicago longitudinal study. Social Work Research, 30(3), 153-167. https://doi.org/ $10.1093 / \mathrm{swr} / 30.3 .153$

Mardapi, D. (2012). Pengukuran, penilaian, dan evaluasi pendidikan. Yogyakarta: Nuha Medika.

Ministry of National Education of Republic of Indonesia. (2011). Petunjuk teknis penyaluran bantuan alat permainan edukatif. Jakarta: Directorate of Early Childhood Education Development, Ministry of
National Education of Republic of Indonesia.

Nugraha, A. (2010). Evaluasi pembelajaran untuk anak usia dini. Bandung: Universitas Pendidikan Indonesia.

Regulation of the Minister of National Education No. 58 of 2009 on the Standard for Early Childhood Education., (2009).

Rushton, S. (2011). Neuroscience, early childhood education and play: We are doing it right! Early Childhood Education Journal, 39(2), 89-94. https://doi.org/ $10.1007 /$ s10643-011-0447-z

Samuelsson, I. P. (2011). Why we should begin early with ESD: The role of early childhood education. International Journal of Early Childhood, 43(2), 103-118. https://doi.org/10.1007/s13158-0110034-x

Sudijono, A. (2011). Pengantar evaluasi pendidikan. Jakarta: Raja Grafindo Persada.

Valentine, K., Thomson, C., \& Antcliff, G. (2009). Early childhood services and support for vulnerable families: Lessons from the Benevolent Society's Partnerships in Early Childhood program. Australian Journal of Social Issues, 44(2), 195-213. https://doi.org/ 10.1002/j.1839-4655.2009.tb00140.x

Woolfolk, A. (2007). Educational psychology (10th ed.). Boston, MA: Allyn \& Bacon. 